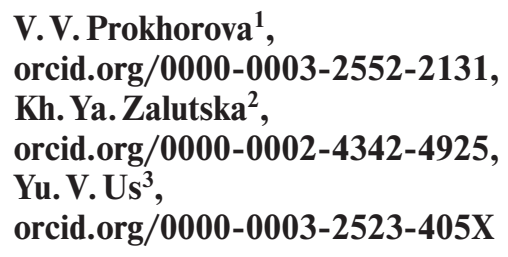

1 - Ukrainian Engineering and Pedagogy Academy, Kharkiv, Ukraine, e-mail: vkprohkorova@gmail.com

2 - Lviv Polytechnic National University, Lviv, Ukraine

3 - Semen Kuznets Kharkiv National University of Economics, Kharkiv, Ukraine

\title{
FORMATION OF MOTIVATIONAL MECHANISM IN STRATEGIC MANAGEMENT OF A DIVERSIFIED ENTERPRISE
}

The successful functioning of a diversified enterprise requires a well-organized team of workers and well-chosen business structures for cooperation and integration to provide balanced and effective development of its business units aimed at the maximum satisfaction of its own interests and achievement of the general goal of the enterprise functioning. The establishment and support of such relations depend significantly on the effective motivational activities both for the enterprise employees (internal ones) and its partners (external ones). At the same time, the intensity of the motivational activities for different business entities depends on the level of their possible influence on the efficiency of the corresponding business entity performance, the level of coordination and optimality of mutual relations between these business entities, and success of the strategic development of the whole diversified enterprise. That is, the motivational activities for different influence groups are different depending on the enterprise mission, the focus of its long-term goals, the chosen strategic way of the development, and others.

Purpose. Consequently, the objective of this article is to elaborate theoretical and methodical recommendations regarding the formation of the complex motivational mechanism of the diversified enterprise by grounding and selection of a motivational system for each influence group attractive for it at a certain point of time (employees, consumers, opponents, and suppliers).

Methodology. To achieve the set objective, the research of this work is conducted using the methods of generalization, abstraction, analysis, synthesis, and situational modeling. The calculation of the efficiency of the proposed activities of the complex motivational mechanism is conducted using the methods of factor analysis, effective competition theory, and integral method.

Findings. The research conducted resulted in the definition of the structure of complex motivational mechanism of the diversified enterprise, description of the features of its external and internal constituents, and formation of the influence groups for each constituent. Possible ways of the combination of important for the enterprise influence groups are formed and of the main conditions for their use are presented depending on the selected general strategy of the enterprise development.

Originality. The novelty of this article involves theoretical and practical recommendations for the formation, implementation, and realization of the activities of the complex motivational mechanism for the diversified enterprise.

Practical value. The activities of the complex motivational mechanism for the JV Spheros-Electron Ltd. have been developed. The key elements of the formation and the methods of realization of the motivational systems for different influence groups of the enterprise under study have been described. The efficiency of the proposed activities has been calculated which proves their effectiveness, soundness of the development, and necessity of realization.

Keywords: influence groups; diversified enterprise; complex motivational mechanism; type of motivational system

Introduction. Considering the modern conditions of the world economic development, the enterprise success requires the implementation of the improved systems of strategic management the efficiency of which significantly depends on a well-formed team of workers. At the same time, to achieve the desired success of a company, the formed team and each member particularly must use their potential to the full (competence, skills, creativity, and so on) aimed at the achievement of the general goals of the enterprise performance via effective fulfillment of the strategy of its development. It can be achieved by implementing the effective internal motivational activities since low wage level and its late payment lead to the decrease in the professional and qualification level of the employees, their moral and creative potential, which further affects the implementation of new technologies, production reorganization, and production of competitive goods.

Besides, the high level of competition in all spheres of the enterprise performance requires the effective selection of both interested in cooperation employees and important for its functioning strategic partners, which can be achieved through the use of the corresponding motivational tools for their stimulation for cooperation. For example, the efficiency of the enterprise performance is significantly influenced by the timeliness, accuracy, specificity of raw materials supply that requires the selection and keeping of the preferred supplier. Such business entities as suppliers, consumers, opponents, or possible partners are the external side of the general motivational system of the enterprise.

(C) Prokhorova V.V., Zalutska Kh.Ya., Us Yu.V., 2021
The formation of the external motivational system is particularly important for the diversified enterprises since in course of their performance they cooperate with different enterprises that depending on the goal of attraction can have a different level of influence (better competitive position in the domestic market, entry into international markets, drop in prices for raw materials, and others) on the development of the diversified enterprise or its business units, which, in this respect, arouses among the authorities of the diversified enterprises interest in and demand for their attraction. Therefore, according to the chosen general way of the diversified enterprise development and the goal of its performance, the relations with different enterprises or their structural units will be different. For example, the cooperation with an enterprise to gain access to some resources for a limited period (when raw materials are needed) and to attract these enterprises in the form of a new business unit or the constituent of the existent business unit for a long-term perspective will require different efforts to persuade the partners to cooperate. That is, the external motivational mechanism of the diversified enterprise is a complex of the motivational systems for different influence groups affecting its development. Herewith, the employees form a separate influence group.

Thus, the issue of the diversified enterprise's complex motivational mechanism formation requires further, more detailed study.

Literature review. Many local and foreign scientists pay attention to the motivation issues; in particular, they:

- offered motivational systems of material incentives of employees that take into account individual bonus indicators 
[1], measures of the improvement of the labour payment organization at the modern enterprise [2], awarding specialists and authorities on the basis of assessing their work results [3], and the system of motivation based on the innovative system of labour payment [4];

- considered different types of non-material (moral) ways of motivation [5, 6], models of the motivational system for the enterprise employees aimed at their development, provision of a comfortable production environment, and realization of labour potential, formation and support of the motivational climate in organization $[7,8]$, and ideal and instructional methods [9]. Some motivational systems take into account both an employee's direct contribution to the enterprise performance and their personal values that provide the achievement of the enterprise goals [10];

- offered the systems of complex motivation that can consist of social and economic and social and psychological processes and combine the interests of an employee and the authorities [11], combine the methods of moral and material stimulation [12] or have limited orientation represented through a systematic approach to the stimulation of the management personnel activity [13], or divide motivation into internal and external believing that the external one is created by incentives and situational factors and the internal one is created by motives, needs, and interests [14].

The scientists also bring out new approaches to the motivation of the employees that imply the improvement of the motivational system: based on the key indicators of an enterprise development efficiency [15]; based on the formation of the motivational mechanism of the enterprise strategic management that combines four constituents of such mechanism (personnel, financial, marketing, and material support) and takes into account the number of motivators and demotivators the analysis and assessment of which allow managing the process of MMSEM at each stage of realization of the enterprise's selected strategy [16].

However, all the proposed motivational activities are focused on the enterprise employees, while the motivational activities focused on the interested consumers, opponents, external partners whose effective activity is no less important for successful development of the diversified enterprise in the strategic perspective are out of the scientists' attention. Thus, motivation should be applied in all spheres of the enterprise performance where the human factor takes place, which leads to the necessity of the complex motivational system formation which would include both internal and external potential zones of influence on the development of the diversified enterprise.

Purpose. The objective of this research is to elaborate theoretical and methodical and practical recommendations for the formation of the complex motivational mechanism of the enterprise by way of grounding and selection of the motivational system for each influence group attractive for it at a certain point of time.

Research goals are:

- to define and characterize the constituents of the complex motivational mechanism;

- to offer variants (types) of the motivational system depending on the influence groups they are meant for within each constituent of the complex motivational mechanism and conditions of their application;

- to form activities for the complex motivational mechanism of the diversified enterprise and calculate their efficiency.

Methods. The application of the methods of analysis, synthesis, situational modelling, and generalization allowed us to define the constituents of the complex motivational mechanism, outline the main influence groups for each constituent, form the possible variants of the relation between different influence groups that formed the basis and promoted the formation of the complex motivational systems types.

The method of abstraction allowed us to form the conditions of implementation of different types of the complex mo- tivational mechanism according to the selected general strategy of the diversified enterprise development under the conditions of growth.

The methods of factor analysis allowed us to calculate the level of efficiency and business activity of JV Spheros-Electron Ltd. before and after possible realization of the proposed activities of the complex motivational mechanism.

The integral method allowed us to calculate the level of conformity of the formed activities of the complex motivational mechanism with the planned indicators of the enterprise performance.

The method of effective competition theory allowed us to define the effect of realization of complex motivational mechanism activities of JV Spheros-Electron Ltd. on the enterprise competitiveness.

Results. The complex motivational mechanism consists of the external and internal constituents each comprising the motivational systems for particular influence groups that are part of the corresponding constituent. Herewith, the influence groups can be defined by different classification features: location (external or internal); interaction variants (cooperation, integration, or partnership); level of influence (intensive, moderate, or low); enterprise interest (significant, moderate, or low), and others.

In this article, we study the influence groups depending on their location and, consequently, form the motivational systems for employees, consumers, opponents, and suppliers.

Thus, the basis of the complex motivational system of a particular enterprise at a particular point of time depending on its type of performance and selected by its strategy of further development will be one of the possible variants of relations between the elements of each system that will consist of different influence groups: Suppliers - employees; Suppliers - clients; Employees - clients; Suppliers - employees - clients; Opponents - employees; Opponents - clients; Opponents suppliers; Opponents - suppliers - clients; Opponents - suppliers - clients - employees; Opponents - employees - clients; Opponents - employees - suppliers.

The volume of the motivational activities for a particular group will depend on the level of their possible influence on the performance of the diversified enterprise or its business units and the necessity of their attraction for the effective development of this enterprise in the strategic period. The features of each type of the motivational systems for different influence groups are presented in Table 1.

Table 1 shows that each type of the motivational system has its pros and cons, however, each of them is valuable for the enterprise at a particular point of time when the corresponding influence groups are interested in cooperation with the diversified enterprise.

Joint Ukrainian and German enterprise Spheros-Electron Ltd. was chosen for the formation of the complex motivational mechanism. The German founder of the enterprise is Spheros $\mathrm{GmbH}$ firm known as Webasto Bus GmbH and the Ukrainian founder of the enterprise is PJSC Concern-Electron.

Spheros-Electron offers air and fluid heaters of different types used in motor-cars and trucks, buses, agricultural, military, and special vehicles, yachts and boats, conditioners for different types of automotive vehicles, installation of "Webasto" ventipanes, and service maintenance of its products [17].

The abovementioned enterprise was chosen based on its proper conditions for the formation and implementation of the complex motivational mechanism activities, in particular:

- it is a diversified enterprise that combines industrial, scientific and manufacturing, trade and service, and financial structures;

- JV Spheros-Electron Ltd. has a well-organized personnel policy that promotes the development of employees professional training;

- a significant share of expenses on goods production (over $63 \%$ in 2017 and $55.3 \%$ in 2018) covers the expenses on the 
Features of Complex Motivational Mechanism Types

\begin{tabular}{|c|c|c|c|c|}
\hline $\begin{array}{l}\text { Complex } \\
\text { motivational } \\
\text { mechanism } \\
\text { type }\end{array}$ & $\begin{array}{c}\mathrm{CMM} \\
\text { constituents }\end{array}$ & $\begin{array}{c}\text { Pros of application of a particular type of the } \\
\text { complex motivational mechanism }\end{array}$ & $\begin{array}{l}\text { Cons of a particular type of the } \\
\text { complex motivational mechanism }\end{array}$ & $\begin{array}{l}\text { Possible strategies of } \\
\text { the enterprise where } \\
\text { it is reasonable to } \\
\text { implement a } \\
\text { particular type of the } \\
\text { CMM }\end{array}$ \\
\hline $\begin{array}{l}\text { External } \\
\text { vertically- } \\
\text { oriented }\end{array}$ & $\begin{array}{l}\text { Suppliers - } \\
\text { Clients }\end{array}$ & $\begin{array}{l}\text { Well-established relations with consumers, } \\
\text { large sales network that grows constantly, } \\
\text { decrease in goods cost by means of discounts } \\
\text { on raw materials, materials, and accessory } \\
\text { parts }\end{array}$ & $\begin{array}{l}\text { Enterprise personnel have no motivation } \\
\text { to work, low work efficiency, fast } \\
\text { personnel turnover, and low quality of } \\
\text { labour resources }\end{array}$ & $\begin{array}{l}\text { Strengthening of } \\
\text { positions on the } \\
\text { market }\end{array}$ \\
\hline $\begin{array}{l}\text { Raw } \\
\text { materials- } \\
\text { oriented }\end{array}$ & $\begin{array}{l}\text { Suppliers - } \\
\text { Employees }\end{array}$ & $\begin{array}{l}\text { High level of labour resources and } \\
\text { realization of labour potential, decrease in } \\
\text { goods cost by means of discounts on raw } \\
\text { materials, materials, and accessory parts }\end{array}$ & $\begin{array}{l}\text { No development of sales network, thus } \\
\text { the enterprise stagnation in terms of its } \\
\text { performance development via the } \\
\text { production of additional existent or new } \\
\text { goods }\end{array}$ & $\begin{array}{l}\text { Backward vertical } \\
\text { integration } \\
\text { (backward) }\end{array}$ \\
\hline $\begin{array}{l}\text { Consumer- } \\
\text { oriented }\end{array}$ & \begin{tabular}{|l|} 
Employees - \\
Clients
\end{tabular} & $\begin{array}{l}\text { Expansion of sales network and } \\
\text { improvement of the enterprise reputation, } \\
\text { high work efficiency }\end{array}$ & $\begin{array}{l}\text { Income increase is achieved only by } \\
\text { means of increasing the volume of } \\
\text { produced goods and depletion of labour } \\
\text { resources, no planning of income growth } \\
\text { by means of goods cost decrease }\end{array}$ & $\begin{array}{l}\text { Forward } \\
\text { vertical } \\
\text { integration (forward) }\end{array}$ \\
\hline $\begin{array}{l}\text { General } \\
\text { vertically- } \\
\text { oriented }\end{array}$ & $\begin{array}{l}\text { Suppliers - } \\
\text { Clients - } \\
\text { Employees }\end{array}$ & $\begin{array}{l}\text { Increase in the enterprise performance } \\
\text { efficiency is achieved by means of decrease } \\
\text { in goods cost, expansion of sales network, } \\
\text { and improvement of labour resources usage }\end{array}$ & $\begin{array}{l}\text { Includes time and funds consumption } \\
\text { for the development, implementation, } \\
\text { and control over the complex } \\
\text { motivational system realization }\end{array}$ & $\begin{array}{l}\text { Full vertical } \\
\text { integration }\end{array}$ \\
\hline $\begin{array}{l}\text { Horizontally- } \\
\text { oriented }\end{array}$ & \begin{tabular}{|l|} 
Opponents - \\
Employees
\end{tabular} & $\begin{array}{l}\text { Effective improvement of the enterprise's } \\
\text { internal processes, the possibility of their } \\
\text { optimization, improvement of goods quality } \\
\text { or new goods production, access to } \\
\text { innovations, and so on }\end{array}$ & $\begin{array}{l}\text { Disregard of the process of the goods } \\
\text { final cost setting, avoidance of the } \\
\text { possibility of application of external } \\
\text { factors for expenses decrease, } \\
\text { omission of raw materials strong features }\end{array}$ & $\begin{array}{l}\text { Horizontal } \\
\text { integration }\end{array}$ \\
\hline $\begin{array}{l}\text { Market- } \\
\text { oriented }\end{array}$ & \begin{tabular}{|l|} 
Opponents - \\
Clients
\end{tabular} & $\begin{array}{l}\text { Improvement of positions in the market, } \\
\text { coverage of its biggest part, or entry into new } \\
\text { markets by means of additional possibilities } \\
\text { of opponents. Access to some types of raw } \\
\text { materials or its lower cost since opponents } \\
\text { can act as suppliers of accessory parts as well }\end{array}$ & \multirow[t]{3}{*}{$\begin{array}{l}\text { Disregard of the enterprise employees, } \\
\text { consequently, if the internal motivational } \\
\text { system was not well-formed up to this } \\
\text { moment, such combination can lead to } \\
\text { ineffective fulfilment of some processes } \\
\text { at the enterprise }\end{array}$} & $\begin{array}{l}\text { Concentric } \\
\text { diversification }\end{array}$ \\
\hline $\begin{array}{l}\text { Raw materials } \\
\text { and } \\
\text { opponent- } \\
\text { oriented }\end{array}$ & \begin{tabular}{|l|} 
Opponents - \\
Suppliers
\end{tabular} & $\begin{array}{l}\text { The possibility of the produced goods price } \\
\text { decrease, its quality improvement by means } \\
\text { of high-quality raw materials }\end{array}$ & & $\begin{array}{l}\text { Horizontal } \\
\text { diversification }\end{array}$ \\
\hline $\begin{array}{l}\text { General } \\
\text { market- } \\
\text { oriented }\end{array}$ & \begin{tabular}{|l|} 
Opponents - \\
Suppliers - \\
Clients \\
\end{tabular} & $\begin{array}{l}\text { Control over goods final cost, the possibility } \\
\text { of entry into new markets, well-organized } \\
\text { goods supply }\end{array}$ & & $\begin{array}{l}\text { Conglomerate } \\
\text { diversification }\end{array}$ \\
\hline $\begin{array}{l}\text { Generally- } \\
\text { oriented }\end{array}$ & \begin{tabular}{|l|} 
Opponents - \\
Suppliers - \\
Clients
\end{tabular} & $\begin{array}{l}\text { The possibility of the enterprise production } \\
\text { process optimization, production of } \\
\text { innovative goods, expansion of the } \\
\text { enterprise, its agencies, and so on }\end{array}$ & $\begin{array}{l}\text { Additional expenses on the formation of } \\
\text { the effective activities of the complex } \\
\text { motivational mechanism }\end{array}$ & $\begin{array}{l}\text { Diagonal } \\
\text { integration }\end{array}$ \\
\hline $\begin{array}{l}\text { Horizontal } \\
\text { consumer- } \\
\text { oriented }\end{array}$ & $\begin{array}{l}\text { Opponents - } \\
\text { Employees - } \\
\text { Clients }\end{array}$ & $\begin{array}{l}\text { Effective sales system, engagement of new } \\
\text { consumers, additional possibilities of the } \\
\text { market development }\end{array}$ & $\begin{array}{l}\text { The necessity to divide consumers into } \\
\text { particular groups so as not to lose some } \\
\text { of them by satisfying their demands with } \\
\text { the same methods and ways }\end{array}$ & $\begin{array}{l}\text { Efforts } \\
\text { intensification aimed } \\
\text { at market develop- } \\
\text { ment }\end{array}$ \\
\hline $\begin{array}{l}\text { Horizontal } \\
\text { raw materials- } \\
\text { oriented }\end{array}$ & \begin{tabular}{|l|} 
Opponents - \\
Employees - \\
Suppliers
\end{tabular} & $\begin{array}{l}\text { Improvement of goods quality, optimization } \\
\text { of the production process and decrease in } \\
\text { expenses on goods production, the } \\
\text { possibility of price manoeuvring, additional } \\
\text { production facilities, and others }\end{array}$ & $\begin{array}{l}\text { Disregard of certain consumers, focus on } \\
\text { the quality and possible decrease in } \\
\text { expenses on goods production can lead to } \\
\text { the production of overpriced goods and/ } \\
\text { or excessive parameters for some clients }\end{array}$ & $\begin{array}{l}\text { Efforts } \\
\text { intensification aimed } \\
\text { at goods develop- } \\
\text { ment }\end{array}$ \\
\hline
\end{tabular}

purchase of raw materials, materials, and accessory parts. Thus, the enterprise should consider suppliers not only at the level of Logistics Department but also should consider this category as a zone of motivational system influence in case of the partnership with JV Spheros-Electron Ltd. with focus on the price policy of appealing suppliers that will cause the decrease in goods cost and increase in income level of JV Spheros-Electron Ltd.;

- steady attraction of the enterprise clients in the domestic market (JSC Cherkasy Bus, PJSC Boryspil Avtoplant, PJSC Au- tokraz, SE Bus Factory "Bohdan", and others) and reluctance to increase their number or improve their quality. Due to the sufficient number of clients at the moment the authorities of the enterprise disregard the improvement of their reputation and search for alternative sales markets for their products which is proved by low expenses on goods sales $(0.25 \%$ in 2017 and $0.09 \%$ in 2018) and the low share of active and stimulation measures for the search for new clients and setting reputation among them. It can indicate the neglect of the effective system of relations with clients and can lead to the loss of some sales markets in the future. 
According to JV Spheros-Electron Ltd. performance peculiarities and the state of the external environment factors the best strategy for its further effective development would be the strategy of full vertical integration, which, based on the data of Table 1, offers the formation of the complex motivational mechanism activities on the basis of the relations between the following influence groups: suppliers, clients, and employees.

Possible activities for the successful realization of JV Spheros-Electron Ltd.'s complex motivational mechanism are given in Table 2.

Possible results of JV Spheros-Electron Ltd. performance after the implementation of the proposed complex motivational mechanism activities are calculated using the indicators that are affected the most by their realization (Table 3 ).

They can include $15 \%$ growth of the net income from goods sales at the account of the sales market expansion (at the same time the sales expenses have also increased by $10 \%$ due to the additional advertisement expenses), decrease in prices on raw materials and other materials by $8 \%$. While doing the calculations it was noted that goods cost would increase along with the increase in sales volume.

The necessity of JV Spheros-Electron Ltd.'s integration with the suppliers and their incorporation into the enterprise as a business unit has been considered. However, the first step toward this goal is the preparation for the appealing suppliers' selection which includes the check on the appealing at first sight suppliers through the cooperation with them for a certain period. Consequently, at first, we considered the cooperation with some suppliers under the terms of raw materials prices decrease through the conclusion of the agreement on goods supply.

All the calculations are done based on the actual data of the enterprise performance studied in 2018.

On the basis of the Table 3 data, JV Spheros-Electron Ltd.'s business activity and profitability were calculated with the possible realization of the proposed complex motivational mechanism activities and without (Table 4). The values of some indicators necessary for the calculation of JV SpherosElectron Ltd.'s business activity and profitability coefficients are given in Table 5.

The Table 4 data show a positive effect of the proposed complex motivational mechanism activities on JV SpherosElectron Ltd.'s profitability and business activity, which is proved by the increased indicators value: assets profitability by the income from the regular performance before tax imposition by $74.84 \%$; own capital profitability by $75.63 \%$; business assets profitability on average by $85 \%$; floating funds turnover coefficient and own capital turnover coefficient by $15 \%$. These data show the intensity of its own funds turnover. Herewith, the period of the floating funds turnover is decreased considering the fact of its growth (in 2018 to 2017) up to this moment.

According to the Table 5 data, JV Spheros-Electron Ltd.'s net profit has increased from 6048 thousand UAH to 10602.98 thousand UAH after the implementation of the complex motivational mechanism activities.

Actions for Realization of JV Spheros-Electron Ltd.'s Complex Motivational Mechanism

\begin{tabular}{|c|c|c|c|}
\hline $\begin{array}{l}\text { Constituent of } \\
\text { the complex } \\
\text { motivational } \\
\text { mechanism }\end{array}$ & $\begin{array}{l}\text { Current state of the } \\
\text { constituent at the enterprise } \\
\text { before the implementation of } \\
\text { the complex motivational } \\
\text { mechanism activities }\end{array}$ & $\begin{array}{l}\text { Key problems resolved by the } \\
\text { proposed motivational } \\
\text { activities }\end{array}$ & $\begin{array}{l}\text { Actions for realization of the complex motivational } \\
\text { mechanism }\end{array}$ \\
\hline $\begin{array}{l}\text { Internal } \\
\text { (labour } \\
\text { resources and } \\
\text { potential) }\end{array}$ & $\begin{array}{l}\text { High wage level, good working } \\
\text { environment, structured work, } \\
\text { strong relations between } \\
\text { employees, and professional } \\
\text { self-improvement are among } \\
\text { used motivational factors }\end{array}$ & $\begin{array}{l}\text { No possibility to communicate with } \\
\text { a wide range of people, credit for } \\
\text { achievements is a rare phenomenon } \\
\text { and only in the form of material } \\
\text { stimulation, no aspiration after the } \\
\text { employees' achievements and } \\
\text { creativity, monotonous work }\end{array}$ & $\begin{array}{l}\text { Organization of periodic meetings for the employees } \\
\text { to be able to communicate and strengthen company } \\
\text { spirit, authorities' moral credit for the employees' } \\
\text { achievements, the possibility to improve qualification } \\
\text { level within the enterprise for the transfer between the } \\
\text { workshops, satisfaction of the need for diversity and } \\
\text { understanding of one's own role in the company }\end{array}$ \\
\hline $\begin{array}{l}\text { External } \\
\text { (suppliers) }\end{array}$ & $\begin{array}{l}\text { The enterprise has a lot of } \\
\text { suppliers whose terms it } \\
\text { accepts and does not demand } \\
\text { their change }\end{array}$ & $\begin{array}{l}\text { The necessity to decrease goods } \\
\text { cost by means of decrease in raw } \\
\text { materials, materials, and accessory } \\
\text { parts price which can be achieved } \\
\text { through the optimization of the } \\
\text { suppliers quantitative and } \\
\text { qualitative characteristics }\end{array}$ & $\begin{array}{l}\text { Optimization of the number of suppliers (selection of } \\
\text { the most appealing ones by certain parameters) } \\
\text { through the definition of their level of appeal and } \\
\text { calculation of the optimum volume of accessory parts } \\
\text { for the effective goods production at the enterprise, } \\
\text { consideration of the possibilities of independent } \\
\text { production of the necessary amount of accessory parts, } \\
\text { their purchase from third party companies or their } \\
\text { independent production and realization to third party } \\
\text { companies, selection of one of the following variants of } \\
\text { possible cooperation with appealing suppliers: to } \\
\text { include them in the structure of the diversified } \\
\text { enterprise in the form of a business unit or a constituent } \\
\text { of the existent business unit; to act as a consumer of } \\
\text { goods of the corresponding (appealing) suppliers. At } \\
\text { the same time, the enterprise must engage the suppliers } \\
\text { for cooperation employing its own name and through } \\
\text { the representation of such cooperation as a necessary } \\
\text { and privileged one for them (for suppliers) }\end{array}$ \\
\hline $\begin{array}{l}\text { External } \\
\text { (clients) }\end{array}$ & $\begin{array}{l}\text { Sufficient quantity of clients in } \\
\text { the Ukrainian and foreign } \\
\text { markets, cooperation with } \\
\text { them is carried out based on } \\
\text { the make to order and on the } \\
\text { basis of concluded contracts }\end{array}$ & $\begin{array}{l}\text { No studies on the needs of } \\
\text { consumers and the possibilities of } \\
\text { the sales market and client base } \\
\text { expansion which increases the risk } \\
\text { of losing the current consumers in } \\
\text { the long-term perspective due to } \\
\text { the disregard of the actions that can } \\
\text { keep strong cooperation with them }\end{array}$ & $\begin{array}{l}\text { Provision of discounts for regular clients, active } \\
\text { advertisement and promotion of its own brand for the } \\
\text { development of the client base, identification of the } \\
\text { strategic area of management (SAM) by certain } \\
\text { criteria for a stronger focus on the needs of each SAM, } \\
\text { estimation of their potential and the necessity of } \\
\text { further cooperation }\end{array}$ \\
\hline
\end{tabular}


Results of JV Spheros-Electron Ltd. Performance in Case of Realization of Proposed Complex Motivational Mechanism Activities

\begin{tabular}{|l|c|c|}
\hline $\begin{array}{c}\text { Indicator name, } \\
\text { thousand, UAH }\end{array}$ & $\begin{array}{c}\text { Actual } \\
\text { value of } \\
2018\end{array}$ & $\begin{array}{c}\text { Value in case of CMM } \\
\text { implementation (regarding } \\
\text { the data of 2018) }\end{array}$ \\
\hline Sales volume & 51087 & 58750.05 \\
\hline $\begin{array}{l}\text { Raw materials, materials, } \\
\text { and accessory parts cost }\end{array}$ & 19823 & 20972.734 \\
\hline Sold goods cost & 36111 & 37994.083 \\
\hline Sales expenses & 2255 & 2480.5 \\
\hline
\end{tabular}

Table 4

JV Spheros-Electron Ltd.'s Profitability and Business Activity Indicators Value with and without Application of Complex Motivational Mechanism Activities

\begin{tabular}{|l|c|c|c|c|}
\hline \multirow{2}{*}{ Indicator } & \multicolumn{2}{|c|}{$\begin{array}{c}\text { Indicator } \\
\text { value }\end{array}$} & \multicolumn{2}{c|}{ Deviations } \\
\cline { 2 - 5 } & $\begin{array}{c}2018 \\
\text { actual }\end{array}$ & $\begin{array}{c}2018 \\
\text { with } \\
\text { CMM }\end{array}$ & abs. & $\%$ \\
\hline \multicolumn{1}{|c|}{ Profitability indicators } & \multicolumn{3}{|c|}{} & \\
\hline $\begin{array}{l}\text { 1. Capital (assets) profitability } \\
\text { by net profit }\end{array}$ & 0.159 & 0.278 & 0.119 & 74.843 \\
\hline 2. Own capital profitability & 0.238 & 0.418 & 0.180 & 75.630 \\
\hline 3. Business assets profitability & 0.263 & 0.489 & 0.226 & 85.932 \\
\hline $\begin{array}{l}\text { 4. Sold goods profitability by } \\
\text { sales income }\end{array}$ & 0.293 & 0.353 & 0.060 & 20.478 \\
\hline 5. Own capital pay-off period & 4.189 & 2.389 & -1.800 & -42.970 \\
\hline \multicolumn{1}{|c|}{ Business activity indicators } & & & & \\
\hline 6. Assets turnover (turnover) & 1.344 & 1.545 & 0.201 & 14.955 \\
\hline $\begin{array}{l}\text { 7. Floating funds turnover } \\
\text { coefficient (turnover) }\end{array}$ & 1.822 & 2.095 & 0.273 & 14.984 \\
\hline $\begin{array}{l}\text { 8. One turnover period of } \\
\text { floating funds (days) }\end{array}$ & 198 & 172 & -26 & -13.131 \\
\hline $\begin{array}{l}\text { 9. Own capital turnover } \\
\text { coefficient }\end{array}$ & 2.015 & 2.318 & 0.303 & 15.037 \\
\hline
\end{tabular}

By summing up the given value of the enterprise's performance indicators, we can say that the implementation of the complex motivational mechanism activities would improve JV Spheros-Electron Ltd.'s performance.
Financial Results of JV Spheros-Electron Ltd.'s Performance Providing Implementation of Complex Motivational Mechanism Activities

\begin{tabular}{|l|c|}
\hline \multicolumn{1}{|c|}{ Indicators } & $\begin{array}{c}\text { Indicator value providing the } \\
\text { realization of the complex } \\
\text { motivational mechanism } \\
\text { activities, thousand, UAH }\end{array}$ \\
\hline Net income from goods sales & 58750.05 \\
\hline Sold goods cost & $(37994.083)$ \\
\hline Gross profit & 20755.967 \\
\hline Other operating incomes & 1327 \\
\hline Administrative expenses & $(6001)$ \\
\hline Sales expenses & $(2480.5)$ \\
\hline Other operating expenses & $(676)$ \\
\hline $\begin{array}{l}\text { Financial result of operating } \\
\text { activity (income) }\end{array}$ & 12925.47 \\
\hline Other financial incomes & 1 \\
\hline Other incomes & 7 \\
\hline Other expenses & $(3)$ \\
\hline $\begin{array}{l}\text { Financial result before tax } \\
\text { imposition (income) }\end{array}$ & 12930.46 \\
\hline Income tax expenses & 2327.48 \\
\hline Net financial result (income) & 10602.98 \\
\hline
\end{tabular}

To set the level of the complex motivational mechanism activities conformity with the planned indicators of the enterprise's performance we used the proposed activities integrated efficiency index.

The internal constituent was assigned the coefficient of 0.5 since this area is affected the most by the enterprise, and the external constituent for each element (suppliers and clients) was assigned the coefficient of -0.25 .

All the indicators are proposed to be evaluated on a scale of 1 to 10 according to their conformity with the standard and planned rate of the enterprise development.

The results of the calculation of the integrated efficiency index of JV Spheros-Electron Ltd.'s complex motivational mechanism activities realization are given in Table 6.

However, the obtained value of the integrated efficiency index of the complex motivational mechanism activities realization does not provide any information about the state of this mechanism but numeric value unless the corresponding interpretation of the results is given. Thus, the obtained value is assigned with the following characteristics: from 0 to 3 is a low

Table 6

Estimation Results of JV Spheros-Electron Ltd.'s Complex Motivational Mechanism Activities Conformity with Planned Indicators Based on Integrated Index

\begin{tabular}{|c|c|c|c|c|c|c|}
\hline \multirow{2}{*}{$\begin{array}{c}\text { CMM } \\
\text { constituent }\end{array}$} & \multirow{2}{*}{ Indicator } & \multicolumn{2}{|c|}{ Rate } & \multirow{2}{*}{$\begin{array}{l}\text { Weighting } \\
\text { factor }\end{array}$} & \multicolumn{2}{|c|}{ Integrated index } \\
\hline & & Act. & Norm. & & Act. & Norm \\
\hline \multirow[t]{2}{*}{ Internal } & Labour potential & 7 & 10 & 0.2 & 1.4 & 2 \\
\hline & Internal motivational system efficiency & 8 & 10 & 0.3 & 2.4 & 3 \\
\hline \multirow{2}{*}{$\begin{array}{l}\text { External- } \\
\text { Clients }\end{array}$} & Increase in current clients' orders volume & 7 & 10 & 0.12 & 0.84 & 1.2 \\
\hline & Sales network expansion with the help of new clients (their quantity) & 6 & 10 & 0.13 & 0.78 & 1.3 \\
\hline \multirow[t]{2}{*}{ Suppliers } & The number of supply agreements concluded for 1 year at least & 8 & 10 & 0.08 & 0.64 & 0.8 \\
\hline & $\begin{array}{l}\text { Decrease in prices for the purchased accessory parts, materials, and raw } \\
\text { materials (in \%) }\end{array}$ & 9 & 10 & 0.17 & 1.53 & 1.7 \\
\hline \multicolumn{5}{|c|}{ Overall efficiency indicator } & 6.19 & 8 \\
\hline
\end{tabular}


level of the complex motivational mechanism activities conformity with the planned value; from 3.1 to 5 is a medium level of conformity; from 5.1 to 7 is a high level of conformity; from 7.1 to 8 is a very high level of conformity of the proposed complex motivational mechanism activities with the planned indicators.

According to the values given in Table 6 and their interpretation, JV Spheros-Electron Ltd.'s complex motivational mechanism activities level of conformity with the planned indicators is high since the obtained value of 6.19 is within the scope of 5.1-7.

Also, the values of the integrated efficiency indicator given in Table 6 for each influence group affecting JV Spheros-Electron Ltd.'s performance can be expressed graphically using the efficiency triangle (Figure), which demonstrates the change in the values of the formed complex motivational mechanism elements and helps to compare them with the standard data. The same efficiency triangle can be constructed using the corresponding efficiency indicators of the motivational activities for different influence groups. The current state of JV SpherosElectron Ltd.'s motivational system that does not take into account the complex approach is expressed on the figure by a dot since the assessment is made only in respect of the internal constituent "employees" with the value of 3.24.

The assessment of JV Spheros-Electron Ltd.'s competitiveness is done using the method of effective competition. Based on this method the most competitive enterprises are ones that have the best-organized work of all structural departments aimed at the efficient use of the resources. This way of the competitiveness assessment comprises the most important results of the enterprise performance, including the duplication of certain indicators, and allows understanding quickly the position of the enterprise in the industry market.

The values of the indicators that characterize the effectiveness of some constituents (structural departments) of JV Spheros-Electron Ltd. are given in Table 8. Each indicator value given in this table is assessed in the following way: 5 points are given to the indicator that has the value lower than the standard

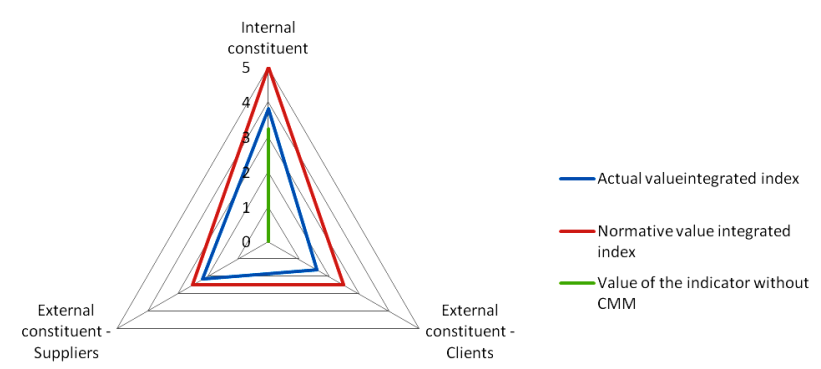

Fig. Triangle of Efficiency of Implementing JV Spheros-Electron Ltd.'s Complex Motivational Mechanism Activities

one; the indicator with the value corresponding to the standard one has 10 points; the indicator with the value higher than the standard one has 15 points. The main year for comparison is 2018. The calculation results are given in Table 7 .

Taking into account that the indicators have a different level of importance for the calculation of the enterprise competitiveness coefficient $\left(K_{C E}\right)$, their weighting factors were found in the following way:

For the calculation of the enterprise competitiveness coefficient $\left(K_{C E}\right)$ the following formula has been used [18]

$$
K_{C E}=0.15 \cdot P_{E}+0.29 \cdot F_{E}+0.23 \cdot O S_{E}+0.33 \cdot K_{C G},
$$

where $P_{E}$ is the value based on the criterion of the enterprise production activity efficiency; $F_{E}$ is the value based on the criterion of the enterprise financial state; $O S_{E}$ is the value based on the criterion of goods sales organization efficiency; $K_{C G}$ is the value based on the criterion of goods competitiveness; $0.15 ; 0.29 ; 0.23 ; 0.33$ are weight coefficients.

The value of the enterprise production activity efficiency $\left(P_{E}\right)$ has been calculated using the following formula [18]

$$
P_{E}=0.31 \cdot V+0.19 \cdot R V+0.4 \cdot P V+0.1 \cdot E V,
$$

where $V$ is the item production expenses value in points; $R V$ is the capital-output ratio value in points; $P V$ is the goods profit-

Results of JV Spheros-Electron Ltd.'s Competitiveness Assessment with and without Application of Complex Motivational

\begin{tabular}{|c|c|c|c|c|c|}
\hline \multirow[b]{2}{*}{ Competitiveness criteria and indicators } & \multicolumn{3}{|c|}{ Absolute value of indicators } & \multicolumn{2}{|c|}{ Value in points } \\
\hline & 2017 & $\begin{array}{c}2018 \\
\text { actual }\end{array}$ & $\begin{array}{c}2018 \\
\text { with CMM }\end{array}$ & $\begin{array}{c}2018 \\
\text { actual }\end{array}$ & $\begin{array}{c}2018 \\
\text { with } \mathrm{CMM}\end{array}$ \\
\hline \multicolumn{6}{|c|}{ 1. Enterprise production activity efficiency } \\
\hline Item production expenses, UAH & 0.697 & 0.706 & 0.646 & 5 & 15 \\
\hline Capital-output ratio, thousand, UAH & 5.721 & 2.359 & 2.713 & 5 & 5 \\
\hline Goods profitability, $\%$ & 43.31 & 41.47 & 54.62 & 5 & 15 \\
\hline Labour efficiency, thousand, UAH/person & 638.285 & 774.045 & 890.152 & 15 & 15 \\
\hline \multicolumn{6}{|c|}{ 2. Enterprise financial state } \\
\hline Autonomy coefficient & 0.651 & 0.667 & 0.667 & 10 & 10 \\
\hline Paying capacity coefficient & 1.857 & 2.008 & 2.008 & 15 & 15 \\
\hline Absolute liquidity coefficient & 0.102 & 0.471 & 0.471 & 15 & 15 \\
\hline Floating funds turnover coefficient & 1.959 & 1.822 & 2.095 & 5 & 15 \\
\hline \multicolumn{6}{|c|}{ 3. Goods sales and promotion efficiency } \\
\hline Sales profitability, $\%$ & 30.243 & 29.31 & 35.329 & 5 & 15 \\
\hline Finished goods glut coefficient & 0.16 & 0.18 & 0.2 & 10 & 10 \\
\hline Advertisement effectiveness and sales stimulation coefficient & 0.031 & 0.086 & 0.060 & 15 & 15 \\
\hline \multicolumn{6}{|c|}{ 4. Goods competitiveness } \\
\hline Goods quality & 85 & 90 & 90 & 10 & 10 \\
\hline Goods price (exemplified by the heater DBW Thermo) & 7.65 & 11.011 & 10.876 & 15 & 10 \\
\hline
\end{tabular}
Mechanism Activities 
ability value in points; $E V$ is the labour efficiency value in points.

The value of the enterprise performance financial state $\left(F_{E}\right)$ was calculated using the following formula [18]

$$
F_{E}=0.29 \cdot K_{Q}+0.2 \cdot K_{p c v}+0.36 \cdot K_{l}+0.15 \cdot K_{f t},
$$

where $K_{a}$ is the enterprise autonomy value in points; $K_{p c v}-$ enterprise paying capacity value in points; $K_{l}$ - enterprise liquidity value in points; $K_{f t}$ - floating funds turnover value in points.

The assessment of goods sales and promotion efficiency $\left(O S_{E}\right)$ has been done using the following formula

$$
O S_{E}=0.38 \cdot R_{E}-0.39 \cdot K_{f E}-0.24 \cdot K_{a s e},
$$

where $R_{s}$ is the sales profitability value in points; $K_{f g}$ is the finished goods glut value in points; $K_{\text {ase }}$ is the advertisement effectiveness and sales stimulation value in points.

0.29 and 0.38 are the weight coefficients for the corresponding indicators.

Goods competitiveness criterion $\left(K_{C G}\right)$ was calculated using the ratio between goods quality value and their consumption price.

Using the data given in Table 7 and the (2-4) we obtained the following values of JV Spheros-Electron Ltd.'s competitiveness constituents:

1. Production activity efficiency:

$P_{E}(2018$ f. $)=0.31 \cdot 5+0.19 \cdot 5+0.40 \cdot 5+0.10 \cdot 15=6$

$P_{E}(2018$ with CMS $)=0.31 \cdot 15+0.19 \cdot 5+0.40 \cdot 15+$ $+0.10 \cdot 15=9.1$.

2. Enterprise performance financial state indicator:

$F_{E}(2018$ actual $)=0.29 \cdot 10+0.20 \cdot 15+0.36 \cdot 15+0.15 \cdot 5=$ $=12.05$

$F_{E}(2018$ with $\mathrm{CMS})=0.29 \cdot 10+0.20 \cdot 15+0.36 \cdot 15+$ $+0.15 \cdot 15=13.55$.

3. Goods sales and promotion efficiency:

$O S_{E}(2018$ actual $)=0.38 \cdot 5+0.39 \cdot 10+0.24 \cdot 15=9.4$

$O S_{E}(2018$ with CMS $)=0.38 \cdot 5+0.39 \cdot 10+0.24 \cdot 15=9.4$.

4. Goods competitiveness:

$K_{C G}(2018$ actual $)=90 / 11.011=8.17$

$K_{C G}(2018$ with CMS $)=90 / 10.876=8.27$.

Herewith, the enterprise competitiveness coefficient is:

$K_{C E}(2018$ actual $)=0.15 \cdot 6+0.29 \cdot 12.05+0.23 \cdot 9.4+$ $+0.33 \cdot 8.17=9.252$

$K_{C E}(2018$ with CMS $)=0.15 \cdot 9.1+0.29 \cdot 13.55+0.23 \cdot 9.4+$ $+0.33 \cdot 8.27=10.185$.

The interpretation of the values obtained was made using the following scale: $K_{C E}<10$ indicates a low level of competitiveness; $10<K_{C E}<20$ indicates a medium level of competitiveness; $K_{C E}>20$ indicates a high level of competitiveness.

According to the results obtained, we can conclude that JV Spheros-Electron Ltd.'s competitiveness does not reach the medium level without the implementation of the complex motivational mechanism activities and equals 9.252. However, in case of the complex motivational mechanism activities implementation, JV Spheros-Electron Ltd.'s competitiveness can, for the same period, increase by $10.08 \%$ and, consequently, cross the medium level line.

Thus, it can be concluded that the implementation of the complex motivational mechanism activities into JV SpherosElectron Ltd. is beneficial and leads to the growth of the financial and business activity indicators and its competitiveness growth that further provides the strengthening of the enterprise positions in the market and development possibilities for new markets takeover when considering more efficient (more sound) motivational activities for the influence groups (clients, employees, and suppliers) under study.

\section{Conclusions.}

The proposed complex motivational mechanism consists of the external and internal motivational systems (constituents). Each motivational system is developed for certain influence groups depending on the strategic way of the diversified enterprise development.
Depending on the combination of certain influence groups at a certain point of time, the types of the complex motivational mechanism have been proposed and characterized and the conditions (general development strategies) where this or that type of the motivational mechanism should be selected have been proposed.

Having analysed JV Spheros-Electron Ltd.'s performance, the authors propose the activities of the general vertically-oriented motivational mechanism based on the relations between the following influence groups (suppliers, clients, and employees). Having studied the features and these groups' level of influence on the enterprise, they suggest the motivational activities for each of them. These activities can stimulate the influence groups to maintain the effective achievement of the set goals through the efficient realization of the selected development strategy.

The calculations of the efficiency of JV Spheros-Electron Ltd.'s complex motivational mechanism activities prove their successfulness. The calculation of the efficiency of the proposed systems was made through the assessment of influence of the motivational activities on the enterprise's financial activity state (based on the indicators of profitability and business activity), the integrated index based on the motivational mechanism constituents, and JV Spheros-Electron Ltd.'s competitiveness using the method of effective competition. The value of the indicators improved in all cases when the complex motivational mechanism activities were applied.

The development and systematization of the conditions and preconditions of the implementation of the complex motivational system of different types into the diversified enterprise performance require further research.

\section{References.}

1. Kovalenko, O. O., \& Kovalenko, S. V. (2016). Dynamic system of individual bonus indicators as a modern instrument of motivation of specialists' effective work. Herald of Economic Science of Ukraine, (2), 95-99.

2. Kostyrko, A. H., \& Mezhenyi, S. O. (2015). Modern state and problematic aspects of labour remuneration in domestic agricultural sector. Scientific herald of Mykolaiv V. O. Sukhomlynskyi National University, 8, 184-187.

3. Shymko, O. V., \& Pidhora, Ye. O. (2017). New approach to changes in the mechanism of specialists and authorities awarding based on the assessment of their competitiveness. Economic Herald of the Donbass, 3(49), 186-189.

4. Pakulina, A.A., Pakulina, H.S., \& Ruban, L.R. (2016). Formation of the innovative system of labour renumeration in the context of Ukrainian economy transformation. The Bulletin of Transport and Industry Economics, 53, 146-150.

5. Mishyna, S. V., \& Mishyn, O. Yu. (2019). Non-material work stimulation as an instrument of improvement of personnel safety at the enterprise. Scientific Bulletin of Mukachevo State University, 20, 582-592. https://doi.org/10.32782/25240072/2019-20-75.

6. Honchar, V.V., \& Obukhova, N.O. (2015). Methods of non-material personnel motivation at industrial enterprises during crisis. Theoretical and practical aspects of economy and intellectual property, 2(3), 125-131.

7. Kunytskyi, M.P. (2017). Motivational climate of political participation: concept definition. Scientific journal "Politicus", 3, 20-24. Retrieved from file:///C:/Users/admin/Downloads/ polit 2017 3 6.pdf.

8. Klymchuk, V. (2015). Motivational discourse of a person: on the way toward social psychology of motivation: monography. Zhytomyr: Zhytomyr Ivan Franko State University Publishing Centre.

9. Shura, N. O., \& Shved, V.V. (2015). Development of the efficient theory of employees motivation at domestic enterprises using the concept of self-development. Agrosvit, 8, 64-69.

10. Pakulina, A. A., Pakulina, H.S., \& Khrystosovna, N.S. (2016). Modernization of motivation system as a preferred way 
of management efficiency development. Path of Science, 2(10), 131-142.

11. Fandieieva, A. Ye. (2014). Suggestions regarding the improvement of personnel behavior (activity) motivation. Scientific Bulletin of Kherson State University, 5(3), 87-91.

12. Klymchuk, A. O., \& Mykhailov, A. M. (2018). Motivation and stimulation of personnel in the effective management of enterprise and development of innovative activity. Marketing and Management of Innovations, 1, 218-234.

13. Pysmenna, M. S. (2014). Systematic approach to the motivation of executive staff. Scientific Bulletin of UNFU, 24(9), 375-383.

14. Bala, V.V., \& Matsak, A. H. (2014). Process of enterprise personnel motivation and its constituents. Technology audit and production reserves, 3(3), 46-50.

15. Bersutska, S. Ya., \& Kamenska, O. O. (2016). Features of the development of industrial enterprise personnel labour motivation according to the strategy. Management of Economy: Theory and Practice. Kyiv: IEF NASU, 110-118.

16. Bielova, O. I. (2015). Efficient motivational mechanism at the enterprise as a key factor of enterprise strategic activity. Functioning of economic systems under post-industrial development. Kharkiv, 28-31.

17. Electron. Spheros-Electron (n.d.). About us. Retrieved from http://spheros.electron.ua.

18. Savchenko, T. V. (2013). Effectiveness assessment of the methods of bakery enterprise competitiveness estimation. State and regions, 1, 143-149.

\section{Формування мотиваційного механізму у стратегічному управлінні диверсифікованого підприємства}

\section{В. В. Прохорова ${ }^{1}$, Х. Я. Залуцька ${ }^{2}$, Ю. В. Ус ${ }^{3}$}

1 - Українська інженерно-педагогічна академія, м. Харків, Україна, e-mail: vkprohkorova@gmail.com

2 - Національний університет «Львівська політехніка», м. Львів, Україна

3 - Харківський національний економічний університет імені Семена Кузнеця, м. Харків, Україна

Успішне функціонування диверсифікованого підприємства вимагає вдало сформованої команди працівників й оптимально підібраних господарських структур для співпраці та інтеграції з метою забезпечення збалансованого й результативного розвитку його бізнес одиниць, спрямованого на максимальне задоволення власних інтересів і досягнення загальної мети існування підприємства. Встановлення й підтримання таких взаємовідносин значною мірою залежить від ефективних мотиваційних заходів як для працівників підприємства (внутрішні), так і зовнішніх партнерів (зовнішні). При цьому, інтенсивність мотиваційних заходів для різних суб'єктів господарювання залежить від рівня їх можливого впливу на ефективність діяльності відповідної бізнес-одиниці, ступеня налагодженості та оптимальності взаємозв'язків між бізнес-одиницями, успішності стратегічного розвитку всього диверсифікованого підприємства. Тобто, мотиваційні заходи для різних груп впливу будуть різними залежно від місії підприємства, спрямованості його довгострокових цілей, обраного стратегічного напрямку розвитку тощо.

Мета. Відповідно, метою статті є розроблення теоретико- методичних і практичних рекомендацій щодо формування комплексного мотиваційного механізму диверсифікованого підприємства шляхом обгрунтування й вибору мотиваційних систем для кожної з привабливих для нього у певний момент часу груп впливу (працівників, споживачів, конкурентів, постачальників).
Методика. Для досягнення мети, дослідження у роботі виконано з використанням методів узагальнення, абстрагування, аналізу, синтезу, ситуаційного моделювання. Розрахунки ефективності пропонованих заходів комплексного мотиваційного механізму здійснені за допомогою методів факторного аналізу, теорії ефективної конкуренції та інтегрального методу.

Результати. У результаті проведених досліджень визначена структура комплексного мотиваційного механізму диверсифікованого підприємства, описані особливості зовнішньої та внутрішньої його складових і виділені групи впливу по кожній складовій. Сформовані можливі варіанти поєднання важливих для підприємства груп впливу та подані основні умови їх використання залежно від обраної загальної стратегії розвитку підприємства.

Наукова новизна. Новизною роботи є теоретикопрактичні рекомендації формування, упровадження й реалізації заходів комплексного мотиваційного механізму для диверсифікованого підприємства.

Практична значимість. Розроблені заходи комплексного мотиваційного механізму для СП ТзОВ «СферосЕлектрон». Розписані особливості формування й заходи реалізації систем мотивації для різних груп впливу досліджуваного підприємства. Розрахована ефективність пропонованих заходів, що підтверджують його результативність, доцільність розробки й необхідність реалізації.

Ключові слова: групи впливу, диверсифіковане підприємство, комплексний мотиваційний механізм, тип мотиваційної системи

\section{Формирование мотивационного механизма в стратегическом управлении диверсифицированного предприятия}

\section{В. В. Прохорова ${ }^{1}$, Х. Я. Залуикая ${ }^{2}$ Ю. В. Ус ${ }^{3}$}

1 - Украинская инженерно-педагогическая академия, г. Харьков, Украина, e-mail: vkprohkorova@gmail.com

2 - Национальный университет «Львовская политехника», г. Львов, Украина

3 - Харьковский национальный экономический университет имени Семена Кузнеца, г. Харьков, Украина

Успешное функционирование диверсифицированного предприятия требует удачно сформированной команды работников и оптимально подобранных хозяйственных структур для сотрудничества и интеграции в целях обеспечения сбалансированного и результативного развития его бизнес-единиц, направленного на максимальное удовлетворение собственных интересов и достижения общей цели существования предприятия. Установление и поддержание таких отношений в значительной степени зависит от эффективных мотивационных мероприятий как для работников предприятия (внутренние), так и внешних партнеров (внешние). При этом интенсивность мотивационных мероприятий для различных субъектов хозяйствования зависит от уровня их возможного влияния на эффективность деятельности соответствующей бизнес-единицы, степени налаженности и оптимальности взаимосвязей между бизнес-единицами, успешности стратегического развития всего диверсифицированного предприятия. То есть, мотивационные мероприятия для различных групп влияния будут разными в зависимости от миссии предприятия, направленности его долгосрочных целей, выбранного стратегического направления развития и тому подобное.

Цель. Соответственно, целью статьи является разработка теоретико-методических и практических рекомендаций по формированию комплексного мотивационного 
механизма диверсифицированного предприятия путем обоснования и выбора мотивационных систем для каждой из привлекательных для него в определенный момент времени групп влияния (работников, потребителей, конкурентов, поставщиков).

Методика. Для достижения цели исследование в работе выполнено с использованием методов обобщения, абстрагирования, анализа, синтеза, ситуационного моделирования. Расчеты эффективности предлагаемых мероприятий комплексного мотивационного механизма осуществлены с помощью методов факторного анализа, теории эффективной конкуренции и интегрального метода.

Результаты. В результате проведенных исследований определена структура комплексного мотивационного механизма диверсифицированного предприятия, описаны особенности внешней и внутренней его составляющих и выделены группы влияния по каждой составляющей. Сформированы возможные варианты сочетания важных для предприятия групп влияния и представлены основные условия их использования в зависимости от выбранной общей стратегии развития предприятия.

Научная новизна. Новизной статьи являются теоретико-практические рекомендации формирования, внедрения и реализации мероприятий комплексного мотивационного механизма для диверсифицированного предприятия.

Практическая значимость. Разработаны мероприятия комплексного мотивационного механизма для СП ООО «Сферос-Электрон». Расписаны особенности формирования и меры реализации систем мотивации для различных групп влияния исследуемого предприятия. Рассчитана эффективность предлагаемых мероприятий, которые подтверждают его результативность, целесообразность разработки и необходимость реализации.

Ключевые слова: группы влияния, диверсифицированное предприятие, комплексный мотивационный механизм, тип мотивационной системы

Recommended for publication by O.A. Karlova, Doctor of Economic Sciences. The manuscript was submitted 04.05.20. 